\title{
Season and sex influences on botanical composi- tion of cattle diets in southern New Mexico
}

\author{
AYED G. MOHAMMAD, C. A. FERRANDO, LEIGH W. MURRAY, REX D. PIEPER, AND \\ JOE D. WALLACE
}

Authors are professor, College of Agriculture, Hebron University, Hebron, West Bank, research scientist, Manfred Expt. Station, INTA Cordoba, Argentina, associate professor, Department of Experimental Statistics, and professors, Department of Animal and Range Sciences, New Mexico State University, Las Cruces, N.M. 88003.

\begin{abstract}
We conducted a study in southern New Mexico to determine seasonal variation in botanical diet composition of cattle and to compare cow and steer diets. The climate and vegetation is typical of semidesert grassland. Fecal samples were obtained from a group of cows and steers during spring, summer, fall, 1989; winter and summer, 1990. Results showed that cattle diets were

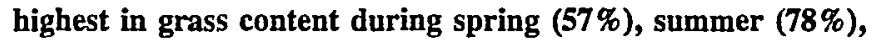
and winter $(54 \%)$, while forbs comprised the highest proportion of cattle diets during the fall (47\%). Shrubs were moderately important during winter (18\%). Dropseeds (Sporobolus spp.), black grama (Bouteloua eriopoda [Torr.] Torr.), threeawn species (Aristida spp.), and leatherweed croton (Croton pottsii [Klotzch] Muell. Arg.) were key forage species for cattle. The importance of these species varied with season, availability, physiological stage, and presence of other species. Differences between cow and steer diets varied with season. The relative similarity ranged from $70 \%$ (fall) to $90 \%$ (summer). The lower fall similarity compared to that in the summer might be related to physiological variation or past differences in grazing experience between cows and steers. For practical purposes, steer diets might generally be used to represent cow diets, but caution should be exercised during periods of low forage quality.
\end{abstract}

\section{Key Words: Diet composition, Semidesert rangeland}

Considerable effort has been devoted to studies of herbivore grazing habits so that animal needs and forage available can be matched to maximize efficiency in converting forage to animal products. Botanical diet composition and animal selectivity are affected by many factors, including season (Obioha et al. 1970, Steger 1971), time spent on pasture (Samuel and Howard 1982), plant species available (Launchbaugh et al. 1990), animal breeds (Walker et al. 1981), kind of animal (Warren et al. 1984), and sex of animal (Miller and Gaud 1990).

Galt et al. (1969) found dict botanical composition of steers on desert grassland changed greatly with time of year and was not the same as available forage. Steers selected plains bristlegrass

\footnotetext{
Contribution from the Agricultural Experiment Station, New Mexico State University, Las Cruces, N.M. 88001 .

Manuscript accepted 27 June 95.
}

(Setaria leucopila Scheum.) as long as it was available, and its contribution to the diet increased as it was utilized heavily. Shrub and cactus species became a part of the diet in the late fall and early winter. In southern New Mexico, Hakkila et al. (1987) found that grasses comprised more than $70 \%$ of cattle diets during the summer and winter, with mesa dropseed (Sporobolus flexuosus [Thurb.] Rydb.) the most important species. They also found forbs and shrubs comprised more than $60 \%$ of the spring and fall diets. These shifts in diet composition were attributed to changes in plant phenology and availability. Similar results were obtained earlier by Rosiere et al. (1975a, 1975b) who indicated cattle diets on desert grassland are dynamic and no fixed seasonal trend can be established to fit all years.

Using steer diets to represent cow diets, or vice versa, is common in botanical diet composition studies. But a clear understanding of the similarities between cow and steer diets is still lacking, and results of the few studies available are unclear. In sheep, Ferrell et al. (1979) found that metabolizable energy and daily dry matter intake was greater for rams than for ewes. Differences in maintenance energy and dry matter intake between the 2 sexes may suggest differences in diet composition and in selectivity by the animals. Miller and Gaud (1990) found that similarity between diets of male and female desert bighom sheep varied from 47 to $80 \%$. On the other hand, Langlands (1969) found that nitrogen content of ram and ewe diets were similar.

The objective of this study was to assess and compare diet composition of cows and steers during different seasons under semidesert grassland conditions.

\section{Study Area and Methods}

This research was part of a project evaluating various aspects of beef cattle production under semidesert conditions, using animals involved in a larger study. Therefore, the procedures followed in this research were adopted considering the total project.

We conducted this study at the New Mexico State University Ranch, $38 \mathrm{~km}$ north of Las Cruces. The study pasture covered 1,400 ha, ranging in elevation from 1,200 to $1,350 \mathrm{~m}$ above sea level, with the topography varying from nearly level to slightly rolling. Several soil associations ranging from fine sandy loams to clay loam soils (Bulloch and Neher 1980), occur on the area. 
Climate is typical of a semiarid grassland: average annual precipitation for a 30-year period was $228 \mathrm{~mm}$, with $56 \%$ occurring from 1 July to 30 September (Dept. of Comm. 1988, 1990). Growing season (June, July, August, and September) rainfall was 23\% above long-term average in 1989 and $7 \%$ above in 1990. The average annual temperature is $16^{\circ} \mathrm{C}$, with June being the hottest month (average maximum temperature $36^{\circ} \mathrm{C}$ ) and January is the coldest (average maximum temperature $13^{\circ} \mathrm{C}$ ). Principal dominant plants are black grama (Bouteloua eriopoda [Torr.] Torr.), mesa dropseed, spike dropseed (Sporobolus contractus A.S. Hitchc.), red threeawn (Aristida longiseta Steud.), tobosa (Hilaria mutica [Buckl.] Benth.), burrograss (Scleropogon brevifolius Phil.), mesquite (Prosopis glandulosa Torr.), soaptree yucca (Yucca elata Engelm.), and broom snakeweed (Gutierrezia sarothrae [Pursh.] Britt. \& Rusby) (Ferrando 1990).

To determine forage availability in each period, we selected four grazing areas according to the concentration of animals grazing. In each grazing area, twenty $0.5 \times 1 \mathrm{~m}$ quadrats were allocated randomly on a transect and all current herbaceous growth was clipped at ground level. In each quadrat, we separated old growth from current growth and discarded it, separated plants by species, and determined dry weight. We used dimension analysis to estimate browse production as described by Ludwig et al. (1975). In each major grazing area, three $2 \times 100 \mathrm{~m}$ belt transects were randomly allocated. We calculated volume of each mesquite, soaptree yucca, and mormon tea (Ephedra trifurca Torr.) rooted in the belt using long and short diameters and height (Ludwig et al., 1975). Finally, we used regression equations to calculate plant biomass.

Sample collections from animals were made 28 May-7 June (20 cows and 6 steers), 19 July 19-8 August (20 cows and 6 steers), 1-17 October (15 cows and 6 steers), 1989; 8-28 January (16 cows and 6 steers), and 23 July- 5 August (16 cows and 4 steers), 1990. These dates represented spring, summer, fall and winter, with summer sampling repeated in 1989 and 1990 . There were 4 sampling dates in each period. The cows, ranging from 6 to 9 years of age, represented 6 genetic groups composed of Hereford, Brangus, Charolais, and Simmental cross-breeding. The steers were two-year old crossbred Red Angus $\times$ Hereford $\times$ Angus. Calves were born in March or April and weaned in October.

All animals grazed together during the entire study period. The cattle were gathered from the study pasture at 0800 hours and moved to a corral, where rectal grab samples of feces were collected and placed in plastic bags. These samples were oven dried at $50^{\circ} \mathrm{C}$ for 48 hours.

Dried samples were ground to $1 \mathrm{~mm}$ in a Wiley mill and mixed for each animal in each period. One composite sample was prepared across days using equal weights of daily samples. Botanical composition of cow and steer diets was determined using the microhistological technique described by Sparks and Malechek (1968). Training for slide reading and plant identification was carried out according to procedures described by Holechek and Gross (1982). To obtain more accurate results, hairs, trichomes, and small particles were disregarded (Holechek and Gross, 1982) and magnification levels of $100 \mathrm{X}$ were used. A $200 \mathrm{X}$ magnification was used when particle characters were unclear (Holechek and Valdez 1985).

Diet overlap between cows and steers were obtained using Kulcyznski's similarity index. The formula

$$
\begin{aligned}
& S=\frac{2 \sum W(100)}{i=1 i} \\
& \begin{array}{l}
S(a+b) \\
i=1 i i
\end{array}
\end{aligned}
$$

was described by Oosting (1956), where $a_{1}$ is the mean amount of species $i$ in diet $a, b_{1}$ is the mean amount of species $i$ in diet $b$, and $W_{1}$ represents $a_{1}$ if $a_{1}<b_{1}$ and $b_{1}$ if $b_{1}<a_{1}$.

Analysis of variance for cows and steers by period for each diet component (\%) used a completely randomized design (Steel and Torrie 1980) and the Statistical Analysis System (SAS) procedure (SAS Institute 1985).

Diet composition of cows and steers across period was analyzed using a split-plot design. Animal category (cow vs. steer) was the whole-plot factor in a completely randomized design with period and the category by period as split plot factors (Steel and Torrie 1980). Only animals (8 cows and 3 steers) present across all periods were used. Where analysis of variance for individual plant component $(\%)$ or forage group detected a significant $F$ value $(P<0.05)$ between periods, mean separations were conducted using the least significant difference (LSD).

\section{Results and Discussion}

\section{Seasonal Variability}

The proportions of total grasses, forbs, and shrubs in cattle diets varied $(\mathrm{P}<0.05)$ among seasons (Table 1$)$. Cattle grazed more grasses $(\mathrm{P}<0.05)$ during summer 1989 and 1990 than during other seasons. Similar results have been reported by Galt et al. (1969), Reppert (1969), Rosiere et al. (1975a), and Hakkila et al. (1987). During summer, grasses are succulent and growing and therefore preferable to cattle. Dropseeds (Sporobolus spp.), black grama, and threeawn species were major grass species contributing to cattle diets. The importance of each species differed among seasons. Dropseeds showed a gradual decrease $(\mathrm{P}<0.05)$ in the contribution to cattle diets as seasons advanced from spring to summer, fall, and winter $(41 \%, 28 \%, 12 \%$, and $3 \%$, respectively). Black grama made the largest contribution during both summer 1989 and 1990 and winter. Threeawn was the major species during fall and summer 1990 and contributed less to cattle diets during spring 1989 and winter 1990.

In fall, when grasses are senescent, their consumption decreased $(\mathrm{P}<0.05)$ compared with other seasons, and cattle shifted their diets more to forbs (Table 1). Similar results were reported by Steger (1971). On the other hand, Rosiere et al. (1975a) found forb contribution to cattle diets was highest during winter; this difference from the current study could be due to variation in annual precipitation and its effect on available forage. Forb species also showed dramatic shifts in their contributions to cattle diets among seasons. Leatherweed croton (Croton pottsii [Klotzch.] Muell.) was consistently important through all seasons, with the highest contribution to cattle diets in the spring. Spurge (Euphorbia spp.) ranged from 0 to $12 \%$ in cattle diets during spring and fall, respectively. During fall and winter, cattle consumption of minor forb species increased, apparently due to decreased availability of green grasses. Other important forb species in some seasons included two-leaf senna (Cassia bauhinoides Gray), Russian thistle (Salsola australis R. Brown), asters 
Table 1. Botanical composition $(\mathscr{O})$ of cattle diets $(D)$ and available forage (AF) at different seasons on desert grassland range $\mathbf{l}^{1 .}$

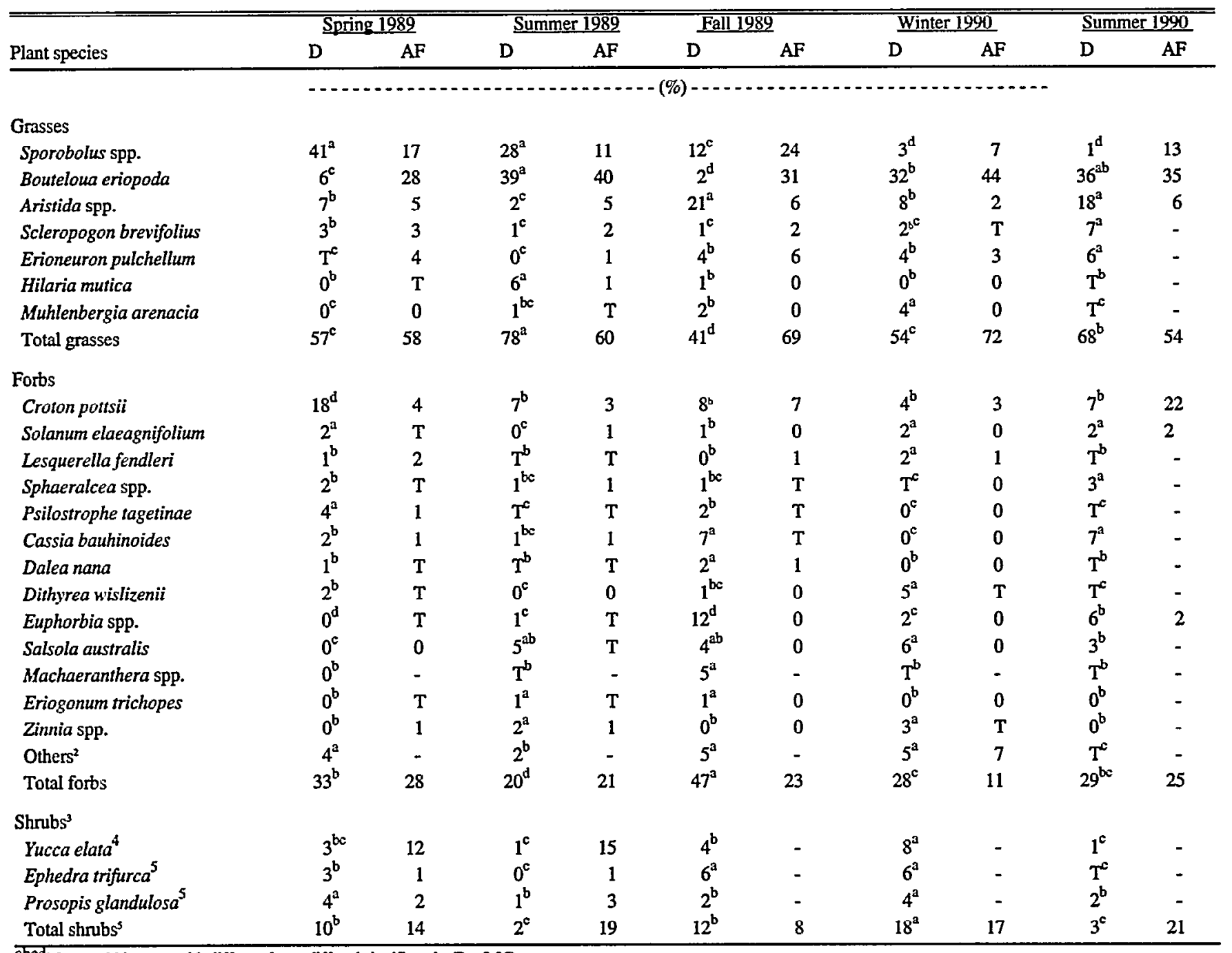

abcd Means within rows with different letter differed significantly $(\mathrm{P}<0.05)$.

$T=$ species identified in trace $(<1 \%)$ amounts.

${ }^{1}$ The sample size was 8 cows and 3 steers.

2 Include unidentified fragments at genus level, and those species show trace amount in some period in cattle diets.

(Machaerenthera spp.), wooly paper flower (Psilostrophe tagetina [Nutt.] Rydb), globemallow (Sphaeralcea spp.), and zinnia (Zinnia spp.) species.

Dietary shrub fractions in cattle diets shifted $(\mathrm{P}<0.05)$ among seasons (Table 1). Shrub consumption decreased from $10 \%$ during spring to $2 \%$ in summer, then increased to $12 \%$ and to $18 \%$ in fall and winter, respectively Cattle increased their shrub consumption in the absence of herbaceous growth. Galt et al. (1969) and Reppert et al. (1969) reported similar results. Dietary content of soaptree yucca, mormon tea, and mesquite was higher $(\mathrm{P}<$ 0.05 ) during winter than other seasons. During other seasons these species provided minor contributions to cattle diets, except for mormon tea during fall.

These results suggest cattle selectivity might be related to animal physiologic status and to plant species availability, phenology, morphology, palatability, and presence of other species. Cattle first focused on green succulent grasses during summer, then shifted to forbs when grasses matured in fall. In winter, herbaceous forage became limited and cattle increased shrub con- sumption. Similar trends have been described by Launchbaugh et al. (1990) in mixed-brush savanna on the Texas Rio Grande plains.

\section{Sex of Animal}

No differences were found between cow and steer diets across seasons in terms of total grasses, forbs, and shrubs (Fig. 1). Among plant groups, cows and steers selected more grass than forbs or shrubs. Grasses were also reported to be the largest plant group in cattle diets on range by Cook et al. (1963); Van Dyne and Heady, (1965), Rosiere et al., (1975b); Walker et al., (1981); Galt et al. (1982); and Launchbaugh et al. (1990). Cows and steers selected different quantities of total grass, forbs, and shrubs among seasons (Table 2), but in some cases these differences were small. During spring (1989) and winter (1990), grasses contributed more $(\mathrm{P}<0.05)$ to the cow diets than to steer diets; and forbs contributed less $(P<0.05)$ to cow diets than steer diets. Shrubs contributed small amounts to both cow and steer diets during the summers of 1989 and 1990. 
Table 2. Means and standard errors (SE) of diet composition ( $(\$)$ of cows and steers on semidesert rangeland ${ }^{1}$.

\begin{tabular}{|c|c|c|c|c|c|c|c|c|c|c|c|c|c|c|c|}
\hline \multirow{2}{*}{$\begin{array}{l}\text { Plant } \\
\text { species }\end{array}$} & \multicolumn{3}{|c|}{ 18 May - 7 June } & \multicolumn{3}{|c|}{19 July - 8 Aug } & \multicolumn{3}{|c|}{$10 \mathrm{ct}-170 \mathrm{ct}$} & \multicolumn{2}{|c|}{ 8 Jan - 28 Jan } & \multicolumn{4}{|c|}{$23 \mathrm{Jul}-4$ Aug } \\
\hline & Cows & Steers & SE & Cows & Steers & SE & Cows & Steers & SE & Cows & Steers & SE & Cows & Steers & SE \\
\hline \multicolumn{16}{|l|}{ Grasses } \\
\hline Sporobolus spp. ${ }^{2}$ & 43 & 41 & 2.0 & 27 & 30 & 2.6 & $20^{\mathrm{a}}$ & $5^{b}$ & 2.0 & 3 & 3 & 0.79 & 1 & 1 & 0.38 \\
\hline Bouteloua eriopoda & 5 & 4 & 1.7 & 39 & 36 & 2.3 & $1^{b}$ & $3^{2}$ & 0.6 & $37^{a}$ & $29^{\circ}$ & 1.97 & 35 & 34 & 1.18 \\
\hline Aristida spp. & 8 & 8 & 1.7 & 2 & 3 & 0.7 & 17 & 22 & 2.1 & 8 & 8 & 0.91 & 19 & 17 & 1.54 \\
\hline Scleropogon brevifolius & 2 & 3 & 0.7 & 1 & 1 & 0.5 & $T^{b}$ & $1^{a}$ & 0.3 & 2 & 1 & 0.37 & 7 & 6 & 1.35 \\
\hline Erioneuron pulchellum ${ }^{2}$ & 1 & $\mathrm{~T}$ & 0.4 & 0 & 0 & 0.0 & $i^{b}$ & $4^{3}$ & 0.7 & 4 & 5 & 0.62 & $4^{b}$ & $7^{\mathrm{a}}$ & 0.98 \\
\hline Hilaria mutica & 0 & 0 & 0.0 & 6 & 7 & 1.0 & 1 & 1 & 0.3 & 0 & 0 & 0.00 & 1 & 0 & 0.36 \\
\hline Mfuhlenbergia arenacia & 0 & 0 & 0.0 & 1 & 1 & 0.4 & 2 & 3 & 0.6 & 3 & 3 & 0.99 & $\mathrm{~T}$ & $\mathrm{~T}$ & 0.26 \\
\hline Total grasses & $59^{3}$ & $57^{b}$ & 1.0 & 77 & 78 & 1.3 & 43 & 39 & 2.3 & $57^{\mathrm{a}}$ & $49^{3}$ & 2.11 & 68 & 65 & 1.97 \\
\hline \multicolumn{16}{|l|}{ Forbs } \\
\hline Croton pottsii & 16 & 18 & 1.4 & 8 & 7 & 1.4 & 7 & 6 & 1.3 & 5 & 5 & 0.79 & $8^{2}$ & $6^{\mathrm{b}}$ & 1.05 \\
\hline Solanum elaeagnifolium & 2 & 1 & 0.8 & 0 & 0 & 0.0 & 1 & 1 & 0.4 & 2 & 3 & 0.44 & 2. & 3 & 0.36 \\
\hline Lesquerella fendleri & 1 & 1 & 0.4 & $\mathbf{T}$ & 0 & 0.1 & 0 & 0 & 0.0 & 1 & 2 & 0.50 & $\mathrm{~T}^{\mathrm{b}}$ & $T^{2}$ & 0.06 \\
\hline Sphaeralcea spp. & 2 & 1 & 0.6 & 1 & 1 & 0.5 & 1 & 2 & 0.6 & $0^{b}$ & $I^{*}$ & 0.10 & $2^{b}$ & $4^{a}$ & 0.45 \\
\hline Psilostrophe tagetinae & 4 & 4 & 0.8 & $\mathbf{T}$ & 0 & 0.1 & 2 & 1 & 0.5 & 0 & 0 & 0.00 & $\mathrm{~T}^{\mathrm{b}}$ & $T^{2}$ & 0.08 \\
\hline Cassia bauhinoides ${ }^{2}$ & $1^{b}$ & $4^{a}$ & 0.5 & $i$ & $\mathrm{~T}$ & 0.6 & 7 & 6 & 1.0 & 0 & 0 & 0.00 & 6 & 8 & 1.03 \\
\hline Dalea nana & 1 & 0 & 0.6 & 1 & 1 & 0.4 & $5^{\mathrm{a}}$ & $1^{b}$ & 1.3 & 0 & 0 & 0.00 & $\mathrm{~T}$ & 0 & 0.28 \\
\hline Dithyrea wislizenii & $\mathrm{T}$ & 3 & 0.4 & 0 & 0 & 0.0 & 1 & 1 & 0.3 & 3 & 3 & 1.01 & 1 & $\mathrm{~T}$ & 0.41 \\
\hline Euphorbia spp & 0 & 0 & 0.0 & $1^{b}$ & $2^{a}$ & 0.4 & $8^{b}$ & $17^{\mathrm{a}}$ & 1.0 & $1^{b}$ & $2^{2}$ & 0.43 & 7 & 7 & 1.01 \\
\hline Salsola australis ${ }^{3}$ & 0 & 0 & 0.0 & 5 & 4 & 0.9 & 6 & 2 & 1.6 & $5^{b}$ & 7 & 0.88 & 5 & 3 & 0.83 \\
\hline Machaeranthera $\mathrm{spp}_{2}^{2}$ & 0 & 0 & 0.0 & $T_{h}$ & 0 & 0.3 & 7 & 4 & 1.8 & $\mathrm{~T}$ & $\mathrm{~T}$ & 0.10 & $\mathrm{~T}$ & $\mathrm{~T}$ & 0.07 \\
\hline Eriogonum trichopes ${ }^{2}$ & 0 & 0 & 0.0 & $\mathrm{~T}^{\mathrm{b}}$ & $T^{3}$ & 0.2 & $\mathrm{~T}$ & $\mathrm{~T}$ & 0.2 & 0 & 0 & 0.00 & $\mathrm{~T}$ & 0 & 0.04 \\
\hline Zinnia spp. ${ }^{2}$ & 0 & 0 & 0.0 & $\mathrm{~T}^{\mathrm{b}}$ & $4^{\mathrm{a}}$ & 0.4 & $T$ & $\mathrm{~T}$ & 0.2 & 3 & 2 & 0.85 & $\hat{\mathrm{T}}$ & 0 & 0.09 \\
\hline Others $^{3}$ & 4 & 3 & 0.6 & $3^{a}$ & $1^{b}$ & 0.5 & $2^{b}$ & $7^{3}$ & 0.8 & 5 & 5 & 0.60 & $\mathbf{T}$ & $\mathrm{T}$ & 0.14 \\
\hline Total forbs & $31^{b}$ & $35^{a}$ & 1.5 & 20 & 20 & 1.5 & 47 & 49 & 2.5 & $25^{\mathrm{b}}$ & $30^{\circ}$ & 1.69 & 30 & 31 & 2.00 \\
\hline \multicolumn{16}{|l|}{ Shrubs } \\
\hline Yucca elata ${ }^{3}$ & 4 & 3 & 1.0 & 3 & 1 & 0.8 & 3 & 4 & 0.7 & 9 & 9 & 1.74 & 2 & 1 & 0.33 \\
\hline Ephedra trifurca ${ }^{4}$ & 3 & 4 & 1.0 & 0 & 0 & 0.0 & 4 & 7 & 1.1 & 5 & 8 & 0.98 & $\mathrm{~T}^{\mathrm{b}}$ & $\mathrm{I}^{\mathrm{a}}$ & 0.09 \\
\hline Prosopis glandulosa ${ }^{4}$ & 4 & 2 & 1.1 & 1 & 1 & 0.4 & 2 & 2 & 0.4 & $4^{b}$ & 5 & 0.54 & $1^{b}$ & $2^{a}$ & 0.33 \\
\hline Total shrubs ${ }^{5}$ & 10 & 8 & 1.3 & $4^{\mathrm{a}}$ & $2^{b}$ & 0.7 & 10 & 12 & 1.3 & 18 & 21 & 1.79 & $3^{b}$ & $4^{a}$ & 0.36 \\
\hline
\end{tabular}

Coefficients of variation between sexes were similar for grass content of the diet and slightly higher for forb and shrub content of steer diets than for cow diets. Variation among animals appeared to be greater for steers than cows during the summer period when additional forage species were available.

The relative similarity between cow and steer diets varied with season (Table 3). Dietary overlap between cows and steers was lowest during fall and highest during spring 1989 and summer 1990. During fall 1989 and winter 1990, contributions of some important species to cow and steer diets differed (Table 2). In both seasons (fall and winter), cows tended $(\mathrm{P}<0.05)$ to consume more grasses and fewer forbs than steers. During fall, diet composition of cows revealed more dropseeds $(\mathrm{P}<0.05)$ and less spurges $(\mathrm{P}<0.05)$ than steers. In winter, cows consumed more black grama $(\mathrm{P}<0.05)$ and less Russian thistle $(\mathrm{P}<0.05)$ than steers. Other less-important species exhibiting differences between cow and steer diets included two-leaf senna during spring 1989; buckwheat (Eriogonum trichopes Torr.) and zinnia during summer 1989; fluffgrass (Erioneuron pulchellum [H. B. K.J) and dwarf dalea (Dalea nana Torr.) during fall 1989; mesquite during winter 1990; and fluffgrass, leatherweed croton, globemallow, and mesquite during summer 1990.

These data show that diet composition of steers and cows were different during spring 1989 and winter 1990. King (1991) found dietary total nitrogen content and digestibility were lowest compared with other seasons during these periods (spring 1989 and winter 1990). These differences might be due to the steers' lack

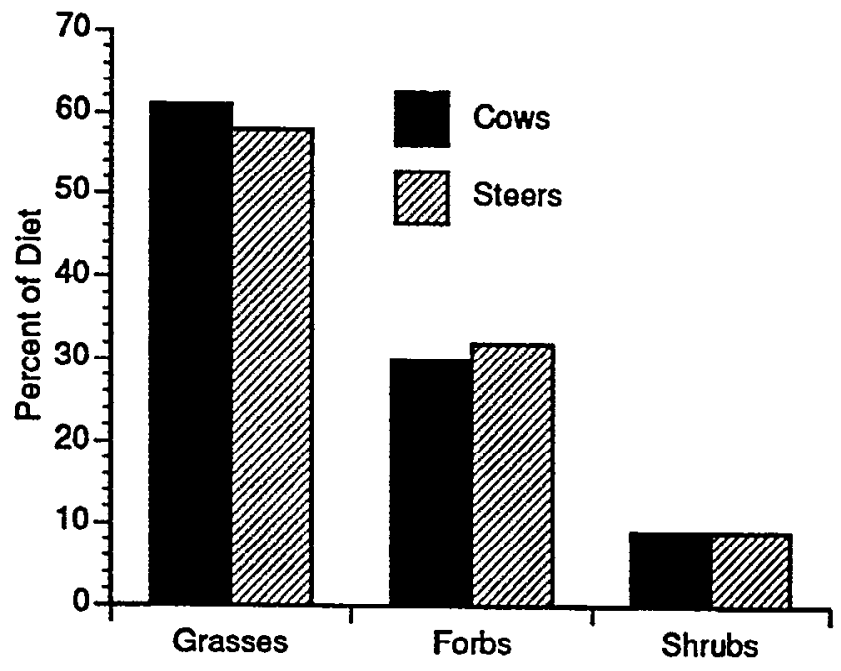

Fig. 1 Average percentage of total grasses, forbs, and shrub content of cow and steer diets across periods. 
Table 3. Dietary overlap (\%) between cows and steers grazing on semidesert rangeland using Kulcyznski's index.

\begin{tabular}{lc}
\hline \hline Period & Diet overlap \\
\hline & $(\%)$ \\
18 May 18 -7 June 1989 & 90 \\
19 Jul 19-8 Aug 1989 & 89 \\
1 Oct 1 - 17 Oct 1989 & 70 \\
8 Jan 8 - 28 Jan 1990 & 87 \\
23 Jul 23 - 4 Aug 1990 & 90 \\
\hline
\end{tabular}

of grazing experience or differences in inherent energy demands between the 2 groups. These results suggest that precautions should be tuken when steer diet compositions are used to represent cow diet compositions particularly during periods of low forage quality.

\section{Conclusion and Implications}

Cattle selected heavily for grass through all seasons except in fall, when forb consumption was greater than grass consumption. Shrubs become a moderately important dietary component during winter when other herbaceous growth was low. Dropseeds, black grama, and threeawn species were the major grasses consumed by cattle; relative importance of these species varied with season. The most important forb species was leatherweed croton. Mesquite, mormon tea, and soaptree yucca were moderately important during winter.

There were no differences in diet composition between cows and steers among seasons. Within seasons, cows consumed more grasses and fewer forbs than steers during spring and winter. In fall, dietary overlap (\%) was lowest between cow and steer diets. For practical purposes, steer diet botanical composition may be used to represent cow diets, but differences between the 2 sexes in diet composition may be greater during periods of unfavorable forage conditions.

\section{Literature Cited}

Bulloch, H. E. Jr. and R. E. Neher. 1980. Soil survey of Dona Ana County area New Mexico. U.S. Dep. Agr. Soil Conserv. Service.

Cook, C. W., J. T. Blake, and J. W. Call. 1963. Use of esophageal-fistula cannulae for collecting forage samples from both sheep and cattle grazing in common. J. Anim. Sci. 22:579-581.

Department of Commerce. 1989. Climatological data, New Mexico. National Oceanic and Atmospheric Administration.

Department of Commerce. 1990. Climatological data, New Mexico. National Oceanic and Atmospheric Administration.

Ferrando, C. A. 1990. Diet botanical composition and fecal chemical indices of cows and steers on semidesert rangeland. M.S. Thesis. New Mexico State University, Las Cruces, N.M.

Ferrell, C. L., J. D. Crouse, R. A. Field, and J. L. Chan. 1979. Effects of sex, diet and stage of growth upon energy utilization by lambs. $J$. Anim. Sci. 49:790-801.

Galt, H. D., B. Theurer, and S. C. Martin. 1982. Botanical composition of steer diets on mesquite and mesquite-free desert grassland. J. Range Manage. 35:320-325.

Galt, H. D., B. Theurer, J. H. Ehrenreich, W. H. Hale, and S. C. Martin. 1969. Botanical composition of diet of steers grazing a desert grassland range. J. Range Manage. 22:14-19.
Hakkila, M. D., J. L. Holechek, J. D. Wallace, D. M. Anderson, and M. Cardenas. 1987. Diet and forage intake of cattle on desert grassland range. J. Range Manage. 40:339-342.

Holechek, J. L. and B. Gross. 1982. Training needed for quantifying simulated diets from fragmented range plants. J. Range Manage. 35:644-647.

Holechek, J. L. and R. Valdez. 1985. Magnification and shrub stemmy material influences on fecal analysis accuracy. J. Range Manage. 38:350-352.

King, D. W. 1991. Seasonal diet quality, intake, and fecal output estimates of steers grazing semidesert rangeland. M. S. Thesis. New Mexico State University, Las Cruces, N.M.

Langlands, J. P. 1969. Studies on the nutritive value of the diet selected by grazing sheep. IV. Variation in the diet selected by sheep differing in age, breed, sex, strain and previous history. Anim. Prod. 11:369-378.

Launchbaugh, K. L., J. W. Stuth, and J. W. Holloway. 1990. Influence of range site on diet selection and nutrient intake of cattle. $J$. Range Manage. 43:109-116.

Ludwig, J. A., J. F. Reynolds, and P. D. Whiston. 1975. Size-biomass relationships of several Chihuahuan desert shrubs. Amer. Midland Natur. 94:451-456.

Miller, G. D. and W. S. Gaud. 1990. Composition and variability of desert bighom sheep diets. J. Wildl. Manage. 53:597-606.

Obioha, F. C., D. C. Clanton, L. R. Rittenhouse, and C. L. Streeter. 1970. Sources of variation in chemical composition of forage ingested by esophageal fistulated cattle. J. Range Manage. 23:133-136.

Oosting, H. J. 1956. The study of plant communities. W. H. Freeman Co., San Francisco, Cal.

Reppert, J. N. 1969. Forage preference and grazing habits of cattle in eastern Colorado. J. Range Manage. 13:58-65.

Rosiere, R. E., J. D. Wallace, and R. F. Beck. 1975a. Cattle diets on semidesert grassland: Nutritive content. J. Range Manage. 28:94-96.

Rosiere, R. E., R. F. Beck, and J. D. Wallace. 1975b. Cattle diets on semidesert grassland: Botanical composition. J. Range Manage. 28:89-93.

Samuel, M. J. and G. S. Howard. 1982. Botanical composition of summer cattle diets on the Wyoming High Plains. J. Range Manage. 35:305-308.

SAS Institute. 1985. SAS User's Guide. Statistics. Statistical Analysis System Institute, Inc., Cary, N.C.

Sparks, D. R. and J. C. Malechek. 1968. Estimating percentage dry weight in diets using a microscopic technique. J. Range Manage. 21:264-265.

Steel, R. G. D. and J. H. Torrie. 1980. Principles and procedures of statistics (second ed.). McGraw Hill Book Co., New York, N.Y.

Steger, R. E. 1971. How does your range vegetation add up? New Mexico State University Coop. Ext. Service Circ. 433.

Van Dyne, G. M. and H. F. Heady. 1965. Botanical composition of sheep and cattle diets on a mature annual range. Hilgardia. 36:465-492.

Walker, J. W., R. M. Hansen, and L. R. Rittenhouse. 1981. Diet selection of Hereford, Angus $x$ Hereford and Charolais $x$ Hereford cows and calves. J. Range Manage. 34:243-245.

Warren, L. E., D. N. Ueckert, and J. M. Sheiton. 1984. Comparative diets of Rambouillet, Barbados, and Karakul sheep and Spanish and Angora goats. J. Range Manage. 37:172-180. 